\title{
International Journal of Management Science and
} Business Administration

Volume 2, Issue 6, May 2016, Pages 42-54

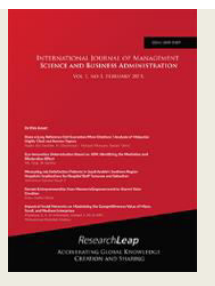

\section{Virtual World - Physical World: What is the Real World?}

\author{
${ }^{1}$ Andries du Plessis, ${ }^{2}$ Bernhardett Theron \\ ${ }^{1}$ Department of Management and Marketing, Unitec New Zealand, Auckland, New Zealand \\ ${ }^{2}$ MBA Programme UUNZ, Institute of Business, Unitec New Zealand, Auckland, New Zealand
}

\begin{abstract}
The purpose of this paper is to investigate the potential growth and use of Virtual World Technology. It is also concerned with the prospects for the routine use of Virtual Worlds in the workplace, the key aspects being the areas in which businesses are using Virtual World. The research design of this paper is descriptive. This research employs the multi-method data collection approach using surveys, where participants answered questions executed through interviews and questionnaires. The study is built on the combination of quantitative and qualitative analysis. All the respondents were familiar with the term Virtual World; and some with long tenures at their organisations, varying from 5 months to more than 22 years in the same field, provided valuable information. Virtual Worlds have created a new social and creative environment where new product development and virtual brands may be created. This paper points out directions, trends and provides indications that would form a sound basis for the necessary future research in Virtual Worlds. The findings of the study affirm that educational systems need to further progress and advance. Further value is that technologies that facilitate resources can be used effectively to promote lifelong learning, and support learner-centred approaches by being vastly available.
\end{abstract}

Keywords: Virtual world, Technology, Product development, Educational systems

\section{Introduction}

Every business today operates in two worlds: a physical world of resources that managers can see and touch, and a Virtual World made of information, it is an emerging convergence of technologies and has become increasingly prominent during the past decade (Badenhorst, 2016; Eisenbeiss et al. 2012; Jarmon 2008; Rayport \& Sviokla 1995).

A Virtual World is an online community that has the form of a computer based simulated environment which enables users to interact with each other and also use and create objects (Bessière, Ellis \& Kellogg 2009). The paper investigates the implementation of Virtual World and 3-D technology in businesses; it also explores how businesses are using Virtual World in different aspects such as training, recruitment and learning; and how it takes place in a face to face environment without leaving the comfort of one's home.

The research investigates the potential growth and use of Virtual World Technology. It is also concerned with the prospects for the routine use of Virtual Worlds in the workplace, the key aspects being the areas in which businesses are using Virtual World (i.e. Training, Learning and Recruitment). A fair number of people are using Second Life and Virtual World as a platform to facilitate meetings of one kind or another, including corporate meetings as well as educational seminars.

\section{Literature Review}

There is a global paradigm shift taking place towards the development of digital economies (Al-Khouri 2012). Virtual Worlds are three-dimensional (3D) persistent multi-user online environments where users interact through avatars and enable new ways of communication, collaboration, and cooperation over the Internet by applying 3D environments and voice over IP technologies (Du Plessis, 2015; Fetscherin \& Lattemann 2008).

Despite hosting an exclusive population, Virtual Worlds offer a rich environment for experiential training, learning and personal connections. Computer-assisted teaching and learning seeks to give students the opportunity to take ownership 
of their own learning. It also seeks to emancipate them from traditional methods that sometimes stifle the freedom to socialise with peers within and beyond the classroom space (Pineteh 2012). A virtual classroom integrates all these resources in one global environment, accessible from the comfort of one's home computer (Mattheos et al. 2001). Virtual World can increasingly play a significant role in training, learning and recruitment.

Table 1: VLE use in educational activities

\begin{tabular}{|c|c|}
\hline VLE used in & VLE used for \\
\hline 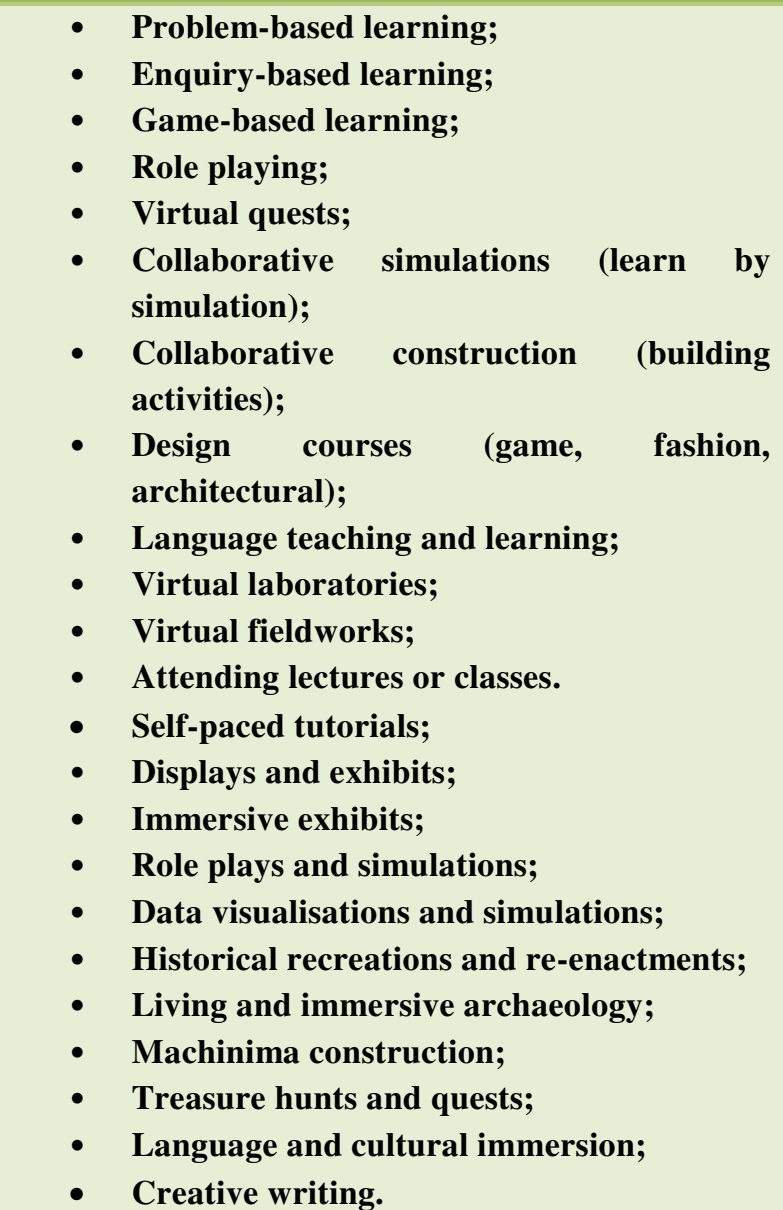 & $\begin{array}{l}\text { - Assessments / grade-book } \\
\text { - Assignments / quizzes } \\
\text { - } \text { Book marking } \\
\text { - Calendar } \\
\text { - Class list and student homepages } \\
\text { - Conferences } \\
\text { - Course outline } \\
\text { - Email tutor and other students } \\
\text { - } \text { File upload area } \\
\text { - Metadata } \\
\text { - Multimedia resources repository } \\
\text { - Navigation model } \\
\text { - Notice-board } \\
\text { - Search tools } \\
\text { - Synchronous collaboration tools }\end{array}$ \\
\hline
\end{tabular}

Source: Adapted from Bell, Castronova \& Wagner, (2009); Wang \& Burton (2013); Britain \& Liber 2004; Haven \& Botterill (2003).

The aim of this paper is to explore how this setting currently facilitates online recruitment, education/learning, and training which is considered a core and extremely important part of any organisation (Johnson et al. 2012); also to be more effective and improvised with the help of Virtual World and to identify those issues of interactivity that are essential in this context (Petrakou 2010). The recent technological developments and the possibilities they offer provide useful tools in the introduction of educational and learning innovations (Barajas \& Owen 2010).

There are numerous contextual definitions and descriptions that have appeared, from the perspectives of writers, academics, industry professionals and the media; the best suited definition for Virtual World is by Schroeder (as cited in Warburton, 2009): A computer-generated display that allows or compels the user (or users) to have a sense of being present in an environment other than the one they are actually in, and to interact with that environment. The educational activities which have been used with the Virtual Learning Environment (VLE) as a way of teaching and learning are illustrated in Table 1 above.

These elements of educational activities are used within the educators' designed projects and are based on different learning theories (Duncan, Miller \& Jiang 2012). Virtual Worlds have been created for many different purposes. The 
largest and most common type of Virtual World is the Massively Multiplayer Online Role Playing Game (MMORPG) (Chandra \& Leenders 2012). Virtual World has been explored beyond gaming and has provided different types of participation in many areas; the five main participation areas of Virtual World are discussed by Gail and Martha (as cited in Kopp \& Burkle 2010). It is illustrated in Table 2 below.

Literature confirms that constant advances in computing and networking technology have converted and evolved the simple text-based Multi User Virtual Environments (MUVEs) into persistent, real-world similarity (3D) Virtual Worlds where multiple users can participate simultaneously to interact with each other and the environment through their graphical representations known as avatars (Wang \& Burton 2013). It is realized that the use of Virtual World has outpaced the understanding of dynamics and unique characteristics of Virtual World. Previously known as a new gaming technology, Virtual World is now used for business purposes as well as in training of medical doctors and many other fields.

Table 2: Virtual World performance in different areas

\begin{tabular}{ll}
\hline TYPE & DESCRIPTION \\
\hline Simulation & $\begin{array}{l}\text { These activities model real world environments and } \\
\text { interactions with people, objects or data within the synthetic } \\
\text { virtual world. This contextualized and situated participatory }\end{array}$ \\
implementation allows participants to safely engage in \\
authentic problem solving, decision making, clinical \\
reasoning, etc. \\
This implementation sets up a pre-made environment ready \\
to be used for instructional activities primarily involved with \\
communication - a court room or a mock interview setting, \\
for example. \\
This implementation allows learners to explore an \\
environment - looking for workplace hazards or \\
familiarization with office layouts and supplies, for example.
\end{tabular}

Source: Kopp \& Burkle (2010, p. 21)

Virtual World can increasingly play a significant role in training, education/learning and recruitment. Several researchers have given their opinions whether it is the end of the road for traditional education models and the beginning of new Virtual Learning Environment (VLE). The shift to virtual interactions seems to signal that the traditional scholarship is phasing out; creating avenues for technologically enhanced learning spaces that can drive meaningful interactivity and intellectual exchanges between students and educators as stated by De Freitas \& Jameson, (2006); Martin \& Madigan, (2006); and Shana, (2009) as cited in Chandra \& Leenders, (2012); Pineteh, (2012). This is further explained in detail in the interviews analysis section.

Implementation of innovative educational practices is purely a response to the social need for educational change. There is a growing body of academic literature that explores the use of Virtual Worlds and avatars in business (AlKhouri 2012; Eisenbeiss et al. 2012;Shen \& Eder 2009) education and learning. As the concept and the structure of such classrooms are relatively new, evaluation only exists in the form of case studies and Cravener (1998) as cited in Mattheos et al., (2001) suggested that web-based virtual environments are likely to support collaborative activities. It 
often can achieve a higher level of interactivity than the one prevailing in traditional face-to face classrooms or boardrooms.

The need for human resources to go on-line not only has grown tremendously, but also become irreplaceable by any other traditional method. Informative, detailed, attractive, and engaging web pages became must haves for a successful company who wants to attract the best job seekers (Gully et al. 2013; Tso, Yau \& Cheung 2010). It is indicated that it is better to learn and make what could be life-threatening mistakes on a computer simulator where the worst case outcome is reset (Allen, Couretas \& Shemwell 2012). Data suggests that the best way to reach the target audience is through the services they use. VLE now covers virtual classrooms in the following fields that can be found in current literature.

- $\quad$ Arts and Humanities;

- Science

- Health Professional

- Information Technology / Computing

- Legal and Business

- Pilot training,

- Anatomy courses

The capability of simulating an actual working environment using Virtual World has yielded another advantage for training and education. The development of the visible human, that displays 3D anatomical details of a male and female human body, together with surgery simulators, has contributed significantly to medical training (Gaggioli et al. 2003; Phillips et al. 2012). This is further supported and confirmed by interviews conducted with a Senior Lecturer of Science and Nursing from Unitec, Auckland. Use of the Internet has grown to over 2.749 billion worldwide (March 2013 figures) with penetration (percentage of population) at $63.2 \%$ for Europe (518 million people online) and $78.6 \%$ for North America (274 million people online). Asia has $27.5 \%$ penetration (1076 million people online), but because of its large population it accounts for $44.8 \%$ of the total Internet population, a figure that has been rising over many quarters according to Duncan, Miller \& Jiang (2012).

Second Life (SL) is currently the most mature and popular 3D MUVE being used in education (Dickey 2011). SL experienced phenomenal growth in 2006 and so was the explorations of SL in education (Bell, Peters \& Pope 2007; Foster 2007; Luo \& Kemp 2008). SL is now considered by many people as the next-generation technology tool for education (Singh \&Lee 2009). People who are separated by distance can engage in social activity of learning in SL. Empirical studies have outgrown the phase of envisioning the use of SL for educational purposes and landed on the phase of empirical explorations after years' evolution. SL enthusiasts emerged from some of the largest corporations, who started establishing their grounds in the parallel Virtual World, where boundary-less opportunities allow holding product launches, promotional campaigns, employment branding and recruitment vehicles, marketing and HR fairs.

However, today the HR industry goes above and beyond job postings through such web pages. Studies have also established that diversity and innovation are the two dimensions that are more frequently communicated via the virtual medium (Braddy, Meade \& Kroustalis 2008). The virtual interactivity of modern recruitment sources, such as Virtual Worlds, permits recruiters to provide applicants with almost instant response or feedback. Numerous companies such as General Motors and IBM started utilizing Virtual Worlds such as SL to build their brands, expand their outreach, and even cut down costs of employee searching and hiring processes (Hasler, Tuchman \& Friedman 2013).

\section{Problem Statement}

To understand the global paradigm shift taking place towards the development of digital economies, with the influence of Virtual World in New Zealand businesses pertaining to Auckland region which is the commercial heart of the country. The article concentrates mainly around the main question which is: "Investigate whether the growth of Virtual World technology is exponential; or is it in its initial stages, and if businesses are able to blend website and Virtual World experiences with their daily operations?" 


\section{Research Objectives}

The primary focus and purpose of this study is to investigate how Virtual Worlds is being used for distance learning, training, recruitment and the secondary purpose is to find out the willingness of companies in applying Virtual World to different sectors of the business. Also to compare the traditional learning method to virtual learning as it will help in finding out the worthiness of investment in Virtual World by determining the type of learning experiences afforded by this 3D Virtual environment (Dickey 2005; Eisenbeiss et al. 2012).

\section{Methodology}

Researchers need to have a clear understanding and appreciation of research methods (Weathington, Cunningham, \& Pittenger, 2012). A research method is a way that a researcher uses to conduct and implement a study (Saunders et al., 2012). This research employs multi-method data collection approach. Multi-method research, is defined as: "the practice of employing different types or styles of data-collecting methods within the same study or research program" (Brewer \& Hunter 2006, p. 577).

This definition indicates that multi-method studies include studies that employ both quantitative and qualitative data collection methods and multiple forms of either qualitative or quantitative methods (Creswell \& Clark 2007). This research design is a descriptive analysis since the focus is to provide an accurate description on the situation; the problem is structured and well understood which is finding the effectiveness and implication of Virtual World in New Zealand businesses and education and determining an accurate answer for the question which is: "what will be the future of Virtual World in the New Zealand market?" Descriptive research may include more than one variable, in this research the researchers have the same situation; they have three main variables which are 1) Training 2) Learning 3) Recruitment (Duncan, Miller \& Jiang 2012).

\subsection{Research Design}

The research design is the overall plan for relating the conceptual research problem to relevant and practicable empirical research (Athanasiou, Debas \& Darzi 2010). In other words, the research design provides a plan or a framework for data collection and its analysis. There are three different types of research design and for each of those designs the problem structure is distinctive (Ghauri \& Gronhaug 2010).
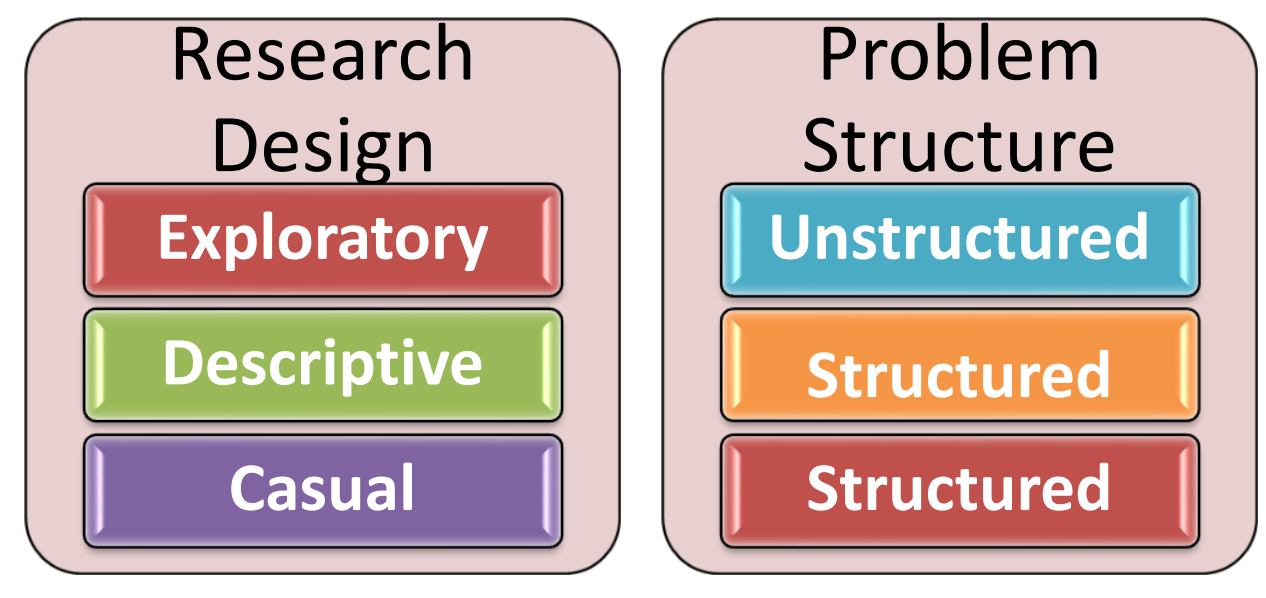

The research design of this research is descriptive. Descriptive research is designed to describe the characteristics or behaviours of a particular population in a systematic and accurate fashion. The key characteristic of a descriptive research are 1) structure 2) Precise rules 3) Procedures (Jackson 2009).

Perception and structure are the keys to a successful descriptive research; the basic steps of descriptive research in order to perform an orderly scientific and disciplined process are (Venkatesh, Brown \& Bala 2012):

- Recognition and identification of a topic to be studied.

- Selecting an appropriate sample of participants.

- Design of information collection procedure.

- Collecting valid and reliable data. 
- $\quad$ Reporting and conclusion.

Descriptive studies are usually the best methods for collecting information that will demonstrate relationships and describe the world as it exists.

There are three main types of descriptive methods (Jackson 2010):

- Observational methods

- Case study methods

- Survey methods.

In this project the researchers have used surveys, where participants answered questions administered through interviews and questionnaires.

\subsection{Sample Size}

Seeking to characterize the current communication ecologies that business and users assemble, the total number of respondents is 92 , of the 150 questionnaires distributed, giving a response rate of $61.3 \%$. There are 7 interviews which consist of top level Executives, Senior Lecturers, Chief Finance officer, Retail insight manager, and a Medical Doctor.

\subsection{Data Collection}

Surveying the Virtual World many existing methods were found of Real World survey research but there are different aspects that need to be understood and discussed (Bell, Castronova \& Wagner 2009). There are three phases of data collection followed in this research:

a). A thorough analysis of the literature review and searching institutional websites to compile a database of staff and teachers who have taken interest or are involved in using 3D immersive Virtual Worlds for learning and teaching

b). The questionnaire were conducted by personal meetings which provided the opportunity for feedback and clarification (Zikmund \& Babin 2007), or electronically delivered to the respondent when distance was an issue.

c). Interviews were conducted to gather different perspectives from teachers, employers, doctors and senior management's point of view.

As this research is based on multi-method data collection, the collection approach is a combination of primary and secondary data. Primary data includes surveys, interviews, participation in SL, observation and so forth and secondary data includes internet statistic websites, international research journals, books, conference proceedings, websites, videos and so on.

\section{Analysis}

The questionnaires and interviews conducted were based on the below table, it included demographic data including age, sex and educational qualifications, general views and awareness about Virtual World, followed by detailed information to analyse their perception towards the use of Virtual World in different aspects of training recruitment and learning.

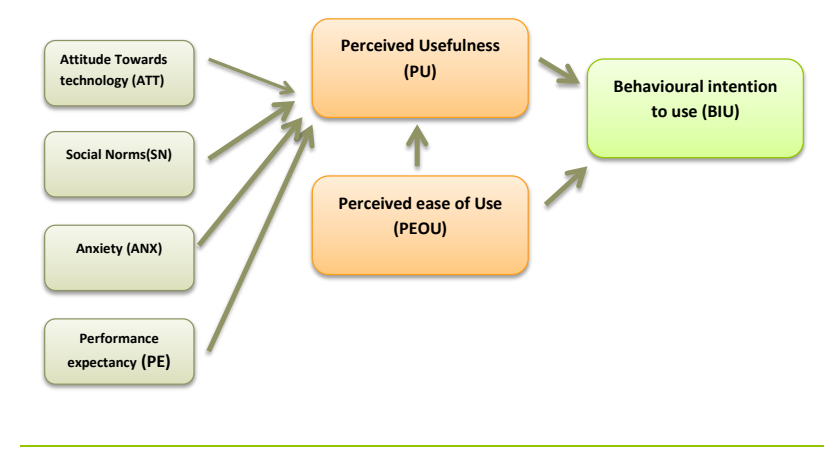

Figure 1: Technology acceptance research model Source: Fetscherin \& Lattemann (2008); Shen \& Eder (2009, p. 226) 


\subsection{Interview discussions and practical findings}

This study is intended to compliment the numerous studies conducted in the past by various researchers. Interviews were conducted to gather more detailed information and perspectives from different fields. A group of 10 people were approached to be interviewed individually, out of which 7 agreed to meet the team, where a structured interview for 20 minutes was conducted to elaborate on their views, experiences, observations and reflections in relation to the use of 3D immersive Virtual Worlds for learning / teaching, training and recruitment.

All the respondents were familiar with the term Virtual World, and with their tenures at their organizations, varying from 5 months to more than 22 years in the same field they provided valuable information. According to the CFO Michael Parrot, from the National Institute of Water and Atmospheric (NIWA) research where the science and research activities is coordinated by their national centres, it offers a wide range of courses each year, presented at a number of venues according to needs and the level of interest. In some instances courses can be presented in-house, and is associated with University of Canterbury, University of Otago and Victoria University Wellington where it supports Post-graduate Centres of Excellence to attract the best students and train them at postgraduate level (PhD and MSc) in areas of growing demand, Virtual World and technology is the life system for NIWA; also promoting creativity, innovation and teamwork is NIWA's mission, hence they allocate approximately $\$ 4$ to $\$ 5$ million each year on technology.

The web-based weather forecasting information service, NIWA, forecasts aims to help farmers and growers identify the right time to carry out weather-dependent operations such as irrigation, spraying and harvesting, which is possible only when teams from different parts of the world communicate and coordinate the forecasts; only Virtual World can minimize the distance (Parrot 2013).

During the interview with Sangeeta Jain, Senior Lecturer, Faculty of Creative Technology, Faculty of Business and Law, AUT University (Jain 2013), she explains that in the context to teaching and learning in VLE, the central players are teachers and students / learners and the main issue faced will be that classrooms, which are isolated from real life, can only simulate reality to a certain extent. Teaching would be a much more complex process as there would be organizational aspects that need to be considered, implicating that to be a good teacher in addition to being a good educator they have to be a good organizer and designer of information, communication, didactical implementation and media integration (Barajas \& Owen 2010). Institutes need to constantly upgraded and create innovative ideas to attract student attention and involve them in the entire learning procedure.

Virtual Worlds have created a new social and creative environment where new product development and virtual brands may be created, students can experiment with their designs on virtual mannequins as communicated by Lyle Reilly (Reilly 2013) Senior Lecturer, Fashion / Product Design Departments, School of Art and Design, AUT University. The CEO from UUNZ Institute of Business, Dr. Jimmy Chen, is of the opinion that UUNZ wants to provide best for its students and is willing to allocate $20 \%$ of their budget on the Virtual Learning as it is a rapidly changing environment and also willing to invest $30 \%$ of their time in training with an expected return of $50 \%$ in the next 5 years. He also suggests that rules and regulations should be in place considering the safety and ethical implications but a mixture of traditional methods where face to face classes are sometimes more effective, hence a blended mode would be preferred (Chen 2013).

A Senior Lecturer from the Department of Health and Science at Unitec, Derek Nash, says that the virtual autopsy is one of the greatest advances in forensic medicine in the past hundred years. With the aid of three-dimensional X-ray techniques, virtual and bloodless autopsies are now being performed due to non-availability of cadavers (Nash 2013). Not only limited to that, hospitals also create a photo-realistic replica of their emergency driveway and entrance, waiting area, intensive care area, delayed treatment, hospital beds, and equipment (Virtual ED II), as well as a variety of both hospital staff and patient avatars. This makes it easy for trainees to navigate the learning space (Heinrichs et al. 2008).

Dr Mala Dutta a renowned Acupuncturist from Auckland remembers her time from training days and feels multiplayer game-based training was more effective than traditional methods; and the virtual environment was useful as practice on live patients is often unpredictable and frequently repetitive. The simulation labs were an extremely useful tool in 
understanding the pressure points of the needles as the Virtual bodies were able to show the response and that too without being hurt (Dutta 2013).

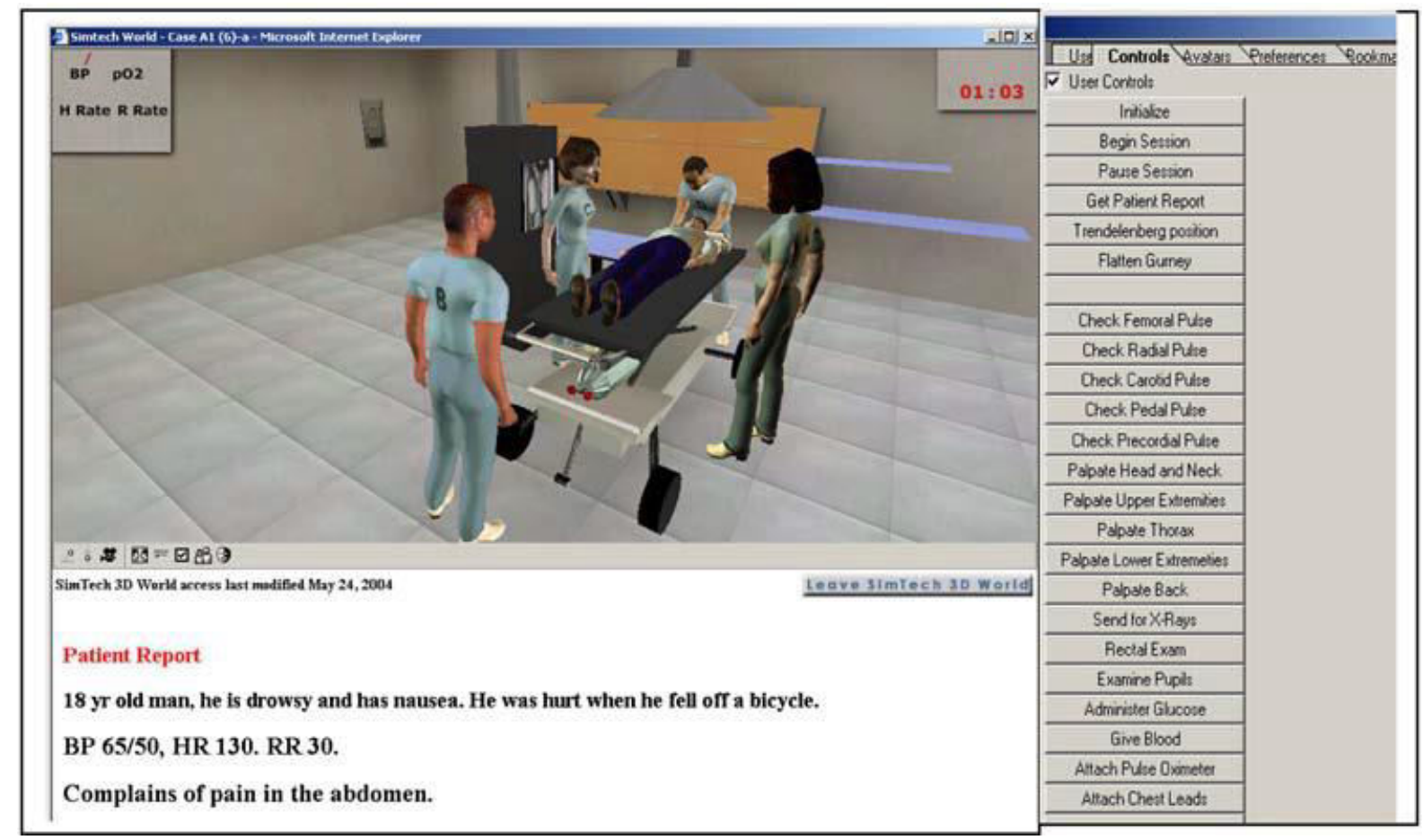

Figure 2: Virtual Simulation

Source: A Virtual Simulation lab (Heinrichs et al. 2008)

An interview with Nilesh Karmokar, a Product Analytics and Insight Manager, Retail Products from Westpac, gave a different insight on Virtual World and recruitment. Westpac uses video conferencing to conduct interviews as it is not so expensive, but the candidate needs to visit the nearest Westpac branch in his/her city. When he was asked what would be Westpac's response to ANZ virtual banking, he comments that Westpac being a huge organization will first see the Return on Investment , and it prefers to spend more money on customers by giving keeping a huge marketing and promotion budget (Karmokar 2013).

\subsection{Data analysis and practical findings.}

Gender frequency distribution:

According to the gender frequency table below it is characterized that 44 persons $(47.8 \%)$ of respondents are female and the rest, 48 persons, $(52.2 \%)$ are male.

Table 3: Gender frequency

\begin{tabular}{|c|l|l|l|l|}
\hline Gender & Frequency & Percentage & $\begin{array}{l}\text { Valid } \\
\text { percentage }\end{array}$ & $\begin{array}{l}\text { Cumulative } \\
\text { percentage }\end{array}$ \\
\hline Female & 44 & 47.8 & 47.8 & 47.8 \\
Male & 48 & 52.2 & 52.2 & 100.0 \\
Total & 92 & 100.0 & 100.0 & \\
\hline
\end{tabular}

Age frequency distribution:

According to the age frequency table it is characterized that 26 respondents (28.3\%) are below 25 years, 26 respondents $(28.3 \%)$ are $26-35$ years, 17 respondents $(18.5 \%)$ are $36-45$ years, 17 respondents $(18.5 \%)$ are $46-55$ years and 6 respondents $(6.5 \%)$ are above 56 years. 
Andries du Plessis, Bernhardett Theron

Virtual World - Physical World: What is the Real World?

Table 4: Age frequency

\begin{tabular}{|l|l|l|l|l|l|}
\hline \multicolumn{2}{|c|}{ Age } \\
\hline \multirow{2}{*2}{} & Frequency & Percentage & $\begin{array}{l}\text { Valid } \\
\text { Percentage }\end{array}$ & $\begin{array}{l}\text { Cumulative } \\
\text { Percentage }\end{array}$ \\
\hline \multirow{5}{*}{ Valid } & Below 25 years & 26 & 28.3 & 28.3 & 28.3 \\
\cline { 2 - 6 } & $26-35$ years & 26 & 28.3 & 28.3 & 56.5 \\
\cline { 2 - 6 } & $36-45$ years & 17 & 18.5 & 18.5 & 75.0 \\
\cline { 2 - 6 } & $46-55$ years & 17 & 18.5 & 18.5 & 93.5 \\
\cline { 2 - 6 } & Above 56 years & 6 & 6.5 & 6.5 & 100.0 \\
\cline { 2 - 6 } & Total & 92 & 100.0 & 100.0 & \\
\hline
\end{tabular}

Educational level frequency distribution:

According to the educational level frequency table it is characterized that $9.8 \%$ of respondents hold a PhD, $21.7 \%$ hold a Masters, 13.0\% have post graduates, 27.2\% hold a Bachelor Degree, 15.2\% have a diploma and 13.0\% attended high school or below.

Table 5: Educational Level

\begin{tabular}{|l|l|l|l|l|l|}
\hline \multicolumn{2}{|c|}{ Educational level } \\
\hline \multicolumn{2}{|c|}{} & Frequency & Percentage & $\begin{array}{l}\text { Valid } \\
\text { Percentage }\end{array}$ & $\begin{array}{l}\text { Cumulative } \\
\text { Percentage }\end{array}$ \\
\hline \multirow{6}{*}{ Valid } & PhD & 9 & 9.8 & 9.8 & 9.8 \\
\cline { 2 - 6 } & Masters & 20 & 21.7 & 21.7 & 31.5 \\
\cline { 2 - 6 } & Post graduates & 12 & 13.0 & 13.0 & 44.6 \\
\cline { 2 - 6 } & Bachelor & 25 & 27.2 & 27.2 & 71.7 \\
\cline { 2 - 6 } & Diploma & 14 & 15.2 & 15.2 & 87.0 \\
\cline { 2 - 6 } & $\begin{array}{l}\text { High school or } \\
\text { below }\end{array}$ & 12 & 13.0 & 13.0 & 100.0 \\
\cline { 2 - 6 } & Total & 92 & 100.0 & 100.0 & \\
\hline
\end{tabular}

Table 6: Descriptive statistics for Virtual World

\begin{tabular}{|c|c|c|c|c|}
\hline \multirow{13}{*}{ 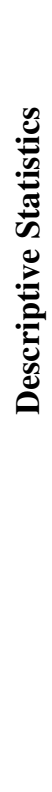 } & & & $\begin{array}{l}\text { Virtual } \\
\text { World }\end{array}$ & $\begin{array}{lll}\begin{array}{l}\text { Valid } \\
\text { wise) }\end{array} & & \text { (list } \\
\end{array}$ \\
\hline & $\mathrm{N}$ & Statistic & 92 & 92 \\
\hline & Range & Statistic & 3.73 & \\
\hline & Minimum & Statistic & 1.27 & \\
\hline & Maximum & Statistic & 5 & \\
\hline & & Statistic & 3.5514 & \\
\hline & & Std. Error & 0.08506 & \\
\hline & $\begin{array}{l}\text { Std. } \\
\text { Deviation }\end{array}$ & Statistic & 0.81588 & \\
\hline & Variance & Statistic & 0.666 & \\
\hline & Skawnecs & Statistic & -0.262 & \\
\hline & 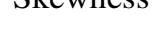 & Std. Error & 0.251 & \\
\hline & $V$ und & Statistic & 0.101 & \\
\hline & Rutusis & Std. Error & 0.498 & \\
\hline
\end{tabular}


Andries du Plessis, Bernhardett Theron

Virtual World-Physical World: What is the Real World?

Table 7: Descriptive statistics for Training

\begin{tabular}{|c|c|c|c|c|}
\hline \multirow{13}{*}{ 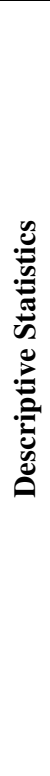 } & & & Training & $\begin{array}{l}\text { Valid N (list } \\
\text { wise) }\end{array}$ \\
\hline & $\mathrm{N}$ & Statistic & 92 & 92 \\
\hline & Range & Statistic & 4 & \\
\hline & Minimum & Statistic & 1 & \\
\hline & Maximum & Statistic & 5 & \\
\hline & $\mathrm{M}_{-}$ & Statistic & 3.7736 & \\
\hline & rvean & Std. Error & 0.07649 & \\
\hline & Std. Deviation & Statistic & 0.73363 & \\
\hline & Variance & Statistic & 0.538 & \\
\hline & $C_{1}$ & Statistic & -0.497 & \\
\hline & SKEWHESS & Std. Error & 0.251 & \\
\hline & & Statistic & 1.014 & \\
\hline & Nurtosis & Std. Error & 0.498 & \\
\hline
\end{tabular}

Table 8: Descriptive statistics for Learning

\begin{tabular}{|c|c|c|c|c|}
\hline \multirow{13}{*}{ 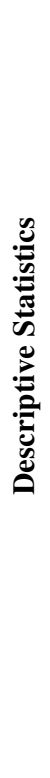 } & & & Learning & $\begin{array}{l}\begin{array}{l}\text { Valid N (list } \\
\text { wise) }\end{array} \\
\end{array}$ \\
\hline & $\mathrm{N}$ & Statistic & 92 & 92 \\
\hline & Range & Statistic & 4 & \\
\hline & Minimum & Statistic & 1 & \\
\hline & Maximum & Statistic & 5 & \\
\hline & Moon & Statistic & 3.9692 & \\
\hline & tritail & Std. Error & 0.07732 & \\
\hline & Std. Deviation & Statistic & 0.74163 & \\
\hline & Variance & Statistic & 0.55 & \\
\hline & & Statistic & -1.009 & \\
\hline & SACWILSS & Std. Error & 0.251 & \\
\hline & & Statistic & 2.097 & \\
\hline & 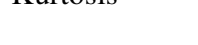 & Std. Error & 0.498 & \\
\hline
\end{tabular}

\section{Recommendations}

It is therefore proposed that there is justification from social science, technology and marketing perspectives for research into this Virtual landscape, which makes the collaborative and community aspects of Virtual Worlds very significant, (Athanasiou, Debas \& Darzi 2010) but companies should also be cautious and invest carefully, as the technology is young and will continue to develop and mature.

- Hospitals and trainee doctors can be benefited if all hospitals could give a virtual tour saving time and making it easy for them to navigate and work together as teams can use all the resources wisely in the event of natural calamity like earthquakes or in the event of any mass casualty.

- The hospitality industries can provide Virtual tours making their resort or hotel more appealing and interesting, also can be used as an extremely good marketing strategy

Retail chains can create Virtual stores where Avatars can interact with customers giving them a different shopping experience. 


\section{Conclusions}

VLE has generated myriads of interpretations globally and been received with mixed feelings. The key lessons learned from previous studies have led us to believe that online teaching and learning are not perfect yet (Alvarez 2005; Papadakis, Paparrizos \& Rossiou 2006). This research project points out to directions, trends and provide indications that would form a sound basis for the necessary future research plans (Mattheos et al. 2001). The findings of the study affirm that educational systems need to further progress and advance (Shana 2009) It is also believed that technologies that facilitate resources can be used effectively to promote lifelong learning, and support learner-centred approaches by being vastly available.

If we do not respond to the academic, linguistic, and cultural diversity of today's world, we are taking the risk of creating systems of low social, educational and economic efficiency. This is the reason why the situation needs a holistic perspective of study and discussion (Barajas \& Owen 2010). Virtual Worlds have great potential for educational use, as is evidenced by the growing range of subjects they have successfully been used for. They offer opportunities, experiences, and pleasures that satisfy many of the basic motivations that drive modern consumption. Yet while "virtual consumption" may be a promising substitute for real consumption, there is a dark side to Virtual Worlds which also present dangers; the most troubling concerns would be dangers of addiction, harmful effects on relationship and values and disconnection from Real World. But every coin has 2 sides, one requires careful reflection before it is whole heartedly embraced and replaced.

\section{References}

- Al-Khouri, AM, 2012, 'Emerging Markets and Digital Economy: Building Trust in the Virtual World'. 57-69, $<$ http://services.igi-global.com/resolvedoi/resolve.aspx?doi=10.4018/jide.2012040105>.

- $\quad$ Allen, P, Couretas, J \& Shemwell, S 2012, "Virtual World Training for Real-World Readiness", Powergrid International, vol. 17 , no. 4 , pp. $10-2$.

- $\quad$ Alvarez, S 2005, 'Blended learning solutions', Encyclopedia of Educational Technology, pp. 1-8.

- $\quad$ Athanasiou, T, Debas, HT \& Darzi, A 2010, Key topics in surgical research and methodology, Springer, CrossRef

- Badenhorst, CJ. 2016. Identifying and Managing the Impact of NeoroLeadership during Organisational Change. LAP Lambert Academic Publishing, Germany

- Barajas, M \& Owen, M 2010, 'Implementing virtual learning environments: Looking for holistic approach', Educational Technology \& Society, vol. 3, no. 3, pp. 39-53.

- Bell, L, Peters, T \& Pope, K 2007, 'Get a (Second) Life: Prospecting for Gold in a 3-D World', Computers in Libraries, vol. 27, no. 1, pp. 10-5.

- Bell, M, Castronova, E \& Wagner, G 2009, 'Surveying the Virtual World-A Large Scale Survey in Second Life Using the Virtual Data Collection Interface (VDCI)', German Council for Social and Economic Data (RatSWD) Research Notes, no. 40.

- $\quad$ Bessière, K, Ellis, JB \& Kellogg, WA 2009, 'Acquiring a Professional Second Life: Problems and prospects for the Use of Virtual Worlds in Business', in CHI'09 Extended Abstracts on Human Factors in Computing Systems: proceedings of theCHI'09 Extended Abstracts on Human Factors in Computing Systems ACM, pp. 2883-98, CrossRef

- $\quad$ Braddy, PW, Meade, AW \& Kroustalis, CM 2008, 'Online recruiting: The effects of organizational familiarity, website usability, and website attractiveness on viewers' impressions of organizations', Computers in Human Behavior, vol. 24, no. 6, pp. 2992-3001, CrossRef

- Brewer, J \& Hunter, A 2006, Foundations of multimethod research: Synthesizing styles, SAGE Publications, Incorporated, California, USA, CrossRef

- Britain, S \& Liber, O 2004, 'A framework for pedagogical evaluation of virtual learning environments'.

- Cabiria, J 2008, 'Virtual world and real world permeability: Transference of positive benefits for marginalized gay and lesbian populations', Journal of Virtual Worlds Research, vol. 1, no. 1.

- Castronova, E \& Wagner, GG 2011, 'Virtual Life Satisfaction', Kyklos, vol. 64, no. 3, pp. 313-28, CrossRef

- Chan, TW 2010, 'How East Asian classrooms may change over the next 20 years', Journal of Computer Assisted Learning, vol. 26, no. 1, pp. 28-52, CrossRef

- Chandra, Y \& Leenders, MAAM 2012, 'User innovation and entrepreneurship in the virtual world: A study of Second Life residents', Technovation, vol. 32, no. 7-8, pp. 464-76, viewed 08/06/2013.

- Charmaz, K \& Belgrave, L 2003, 'Qualitative interviewing and grounded theory analysis', Sage, Thousand Oaks, CA, pp. 311-30.

- Chen, DJ 2013, Virtual Learning Environment, Auckland New Zealand, CEO, UUNZ Institute of Business. 
- Collier, L, Dunham, S, Braun, MW \& O'Loughlin, VD 2012, 'Optical versus virtual: Teaching assistant perceptions of the use of virtual microscopy in an undergraduate human anatomy course', Anatomical Sciences Education, vol. 5, no. 1, pp. 10-9, CrossRef

- Coolican, H 2013, Research methods and statistics in psychology, Routledge.

- Cravener, P 1998, 'Education on the Web: A rejoinder', Computer, vol. 31, no. 9, pp. 107-8, CrossRef

- Creswell, JW \& Clark, VLP 2007, Designing and conducting mixed methods research, Wiley Online Library, London.

- Dalgarno, B, Lee, MJ, Carlson, L, Gregory, S \& Tynan, B 2011, 'An Australian and New Zealand scoping study on the use of 3D immersive virtual worlds in higher education', Australasian Journal of Educational Technology, vol. 27, no. 1, pp. 115, CrossRef

- De Freitas, S \& Jameson, J 2006, 'Collaborative e - support for lifelong learning', British journal of educational technology, vol. 37, no. 6, pp. 817-24, CrossRef, CrossRef

- Dickey, MD 2005, 'Three - dimensional virtual worlds and distance learning: two case studies of Active Worlds as a medium for distance education', British journal of educational technology, vol. 36, no. 3, pp. 439-51, CrossRef

- Dickey, MD 2011, 'The pragmatics of virtual worlds for K-12 educators: investigating the affordances and constraints of Active Worlds and Second Life with K-12 in-service teachers', Educational technology research and development, vol. 59, no. 1, pp. 1-20, CrossRef

- Du Plessis, AJ, 2015 (general editor). Munyeka, W, Chipunza, C, Samuel, MO, Naidoo, K, Keyser, E \& Gura, M. HRM and ER in South Africa: contemporary theory and practice. Juta Publishers, Cape Town, South Africa.

- Duncan, I, Miller, A \& Jiang, S 2012, 'A taxonomy of virtual worlds usage in education', British journal of educational technology, vol. 43, no. 6, pp. 949-64, CrossRef

- Dutta, M 2013, Virtual Learning and Training Environment: Accupunture Associates, New Zealand.

- $\quad$ Eisenbeiss, M, Blechschmidt, B, Backhaus, K \& Freund, PA 2012, '"The (Real) World Is Not Enough:" Motivational Drivers and User Behavior in Virtual Worlds', Journal of Interactive Marketing, vol. 26, no. 1, pp. 4-20, CrossRef

- Fetscherin, M \& Lattemann, C 2008, 'User acceptance of virtual worlds', Journal of Electronic Commerce Research, vol. 9, no. 3, pp. 231-42.

- $\quad$ Firestone, WA 1987, 'Meaning in Method: The Rhetoric of Quantitative and Qualitative Research', Educational researcher, vol. 16, no. 7, pp. 16-21, CrossRef

- Foster, AL 2007, 'Professor Avatar: In the Digital Universe of Second Life, Classroom Instruction Also Takes on a New Personality', Chronicle of Higher Education, vol. 54, no. 4.

- Gaggioli, A, Mantovani, F, Castelnuovo, G, Wiederhold, B \& Riva, G 2003, 'Avatars in clinical psychology: a framework for the clinical use of virtual humans', Cyberpsychology \& behavior, vol. 6, no. 2, pp. 117-25, CrossRef

- Ghauri, P \& Gronhaug, K 2010, Research Methods in Business Studies, 4th edn, Pearson Education Limited, Prentice Hall, Europe.

- Gully, SM, Phillips, JM, Castellano, WG, Han, K \& Kim, A 2013, 'A Mediated Moderation Model of Recruiting Socially and Environmentally Responsible Job Applicants', Personnel Psychology, CrossRef

- Harwood, T \& Ward, B 2013, 'Market research within 3D virtual worlds: An examination of pertinent issues', International Journal Of Market Research, vol. 55, no. 2, pp. 247-56, CrossRef

- Hasler, BS, Tuchman, P \& Friedman, D 2013, 'Virtual research assistants: Replacing human interviewers by automated avatars in virtual worlds', Computers in Human Behavior, vol. 29, no. 4, pp. 1608-16, CrossRef

- Haven, C \& Botterill, D 2003, 'Virtual learning environments in hospitality, leisure, tourism and sport: A review', Journal of Hospitality, Leisure, Sport and Tourism Education, vol. 2, no. 1, pp. 75-92, CrossRef

- Heinrichs, WL, Youngblood, P, Harter, PM \& Dev, P 2008, 'Simulation for team training and assessment: case studies of online training with virtual worlds', World Journal of Surgery, vol. 32, no. 2, pp. 161-70, CrossRef

- Jackson, SL 2010, Research methods: a modular approach, Wadsworth Publishing Company.

- Jain, S 2013, Virtual Learning Environment, New Zealand, <Senior Lecturer, Faculty of Creative Technology, Faculty of Business and Law, AUT University $>$.

- Jarmon, L 2008, 'Pedagogy and learning in the virtual world of Second Life', Encyclopedia of distance and online learning, vol. 3, pp. 1610-9.

- Johnson, SK, Garrison, LL, Hernez-Broome, G, Fleenor, JW \& Steed, JL 2012, 'Go for the goal (s): Relationship between goal setting and transfer of training following leadership development', Academy of Management Learning \& Education, vol. 11, no. 4, pp. 555-69, CrossRef

- Karmokar, N 2013, Virtual Recruitment and Training, Westpac New Zealand Limited: Product Analytics and Insight Manager, Retail Products.

- $\quad$ Kopp, G \& Burkle, M 2010, 'Using second life for just-in-time training: building teaching frameworks in virtual worlds', International Journal of Advanced Corporate Learning, vol. 3, pp. 19-25, CrossRef

- Luo, L \& Kemp, J 2008, 'Second Life: Exploring the immersive instructional venue for library and information science education', Journal of Education for Library and Information Science, pp. 147-66.

- Mac Kenzie, K, Buckby, S \& Irvine, H 2013, 'Business research in virtual worlds: possibilities and practicalities', Accounting, Auditing \& Accountability Journal, vol. 26, no. 3, pp. 352-73, CrossRef 
- $\quad$ Martin, A \& Madigan, D 2006, Digital literacies for learning, Facet Publishers, London.

- Mattheos, N, Nattestad, A, Schittek, M \& Attström, R 2001, 'A virtual classroom for undergraduate periodontology: a pilot study', European Journal of Dental Education, vol. 5, no. 4, pp. 139-47, CrossRef

- McNabb, DE 2010, Research methods for political science: quantitative and qualitative approaches, ME Sharpe.

- Meredith, S \& Newton, B 2003, 'Models of eLearning: Technology promise vs learner needs literature review', The International Journal of Management Education, vol. 3, no. 3, pp. 43-56, CrossRef

- Nash, D 2013, Virtual Learning Environment, Senior Lecturer, Faculty of Social and Health Sciences Unitech University, Auckland, New Zealand

- Nel, P, Werner, A, Du Plessis, A, Ngalo, O, Poisat, P, Sono, T, Van Hoek, L \& Botha, C 2011, Human Resource Management. Cape Town, Oxford University Press.

- $\quad$ Papadakis, S, Paparrizos, K \& Rossiou, E 2006, 'Using Blended Learning in Traditional Face-to-Face Instruction: A case study teaching Algorithms to undergraduate students', in World Conference on E-Learning in Corporate, Government, Healthcare, and Higher Education: proceedings of theWorld Conference on E-Learning in Corporate, Government, Healthcare, and Higher Education pp. 839-45.

- Parrot, M 2013, Chief Finance Officer at National Institute of Water and Atmospheric Research, <Virtual world for Training and Recruitment>.

- Petrakou, A 2010, 'Interacting through avatars: Virtual worlds as a context for online education', Computers \& Education, vol. 54, no. 4, pp. 1020-7, CrossRef

- $\quad$ Phillips, D, Duke, M, Nagle, C, Macfarlane, S, McNolty, G, Lane, P, Fox, I \& Patterson, D 2012, 'Students' expectations of the virtual maternity clinic', in ASCILITE 2009: Same places, different spaces: Proceedings of the 26th ASCILITE conference: proceedings of the ASCILITE 2009: Same places, different spaces: Proceedings of the 26th ASCILITE conference Australian Society for Computers in Learning in Tertiary Education, pp. 791-5.

- Pineteh, EA 2012, 'Using virtual interactions to enhance the teaching of communication skills to information technology students', British journal of educational technology, vol. 43, no. 1, pp. 85-96, CrossRef

- $\quad$ Rayport, JF \& Sviokla, JJ 1995, 'Exploiting the virtual value chain', Harvard Business Review, vol. 73, pp. 75-85.

- $\quad$ Reilly, L 2013, Virtual Learning Environment New Zealand, <Senior Lecturer, Fashion/ Product Design Depts, School of Art and Design, AUT University,>.

- $\quad$ Royle, M \& Hall, A 2012, 'The relationship between McClelland's theory of needs, feeling individually accountable, and informal accountability for others', International Journal of Management and Marketing Research, vol. 5, no. 1, pp. 21-42.

- Schroeder, R 1996, Possible worlds: the social dynamic of virtual reality technology, Westview Press, Inc.

- $\quad$ Schroeder, R 2008, 'Defining virtual worlds and virtual environments', Journal of Virtual Worlds Research, vol. 1, no. 1.

- Shana, Z 2009, 'Learning with technology: Using discussion forums to augment a traditional-style class', Educational Technology \& Society, vol. 12, no. 3, pp. 214-28.

- Shen, J \& Eder, LB 2009, 'Intentions to use virtual worlds for education', Journal of Information Systems Education, vol. 20, no. 2, p. 225.

- $\quad$ Singh, N \& Lee, MJ 2009, 'Exploring Perceptions Toward Education in 3-D Virtual Environments: An Introduction to "Second Life"', Journal of Teaching in Travel \& Tourism, vol. 8, no. 4, pp. 315-27, CrossRef

- Smith, JK 1983, 'Quantitative versus qualitative research: An attempt to clarify the issue', Educational researcher, vol. 12, no. 3, pp. 6-13, CrossRef

- $\quad$ Strauss, A \& Corbin, J 1994, 'Grounded theory methodology', Handbook of qualitative research, pp. 273-85.

- Tso, GK, Yau, KK \& Cheung, MS 2010, 'Latent constructs determining Internet job search behaviors: Motivation, opportunity and job change intention', Computers in Human Behavior, vol. 26, no. 2, pp. 122-31, CrossRef

- $\quad$ Turner, T, Qvarfordt, P, Biehl, JT, Golovchinsky, G \& Back, M 2010, 'Exploring the workplace communication ecology', in Proceedings of the 28th international conference on Human factors in computing systems: proceedings of the Proceedings of the 28th international conference on Human factors in computing systems ACM, pp. 841-50, CrossRef

- Venkatesh, V, Brown, S \& Bala, H 2012, 'Bridging the qualitative-quantitative divide: Guidelines for conducting mixed methods research in information systems', MIS Quart. Forthcoming.

- Wang, F \& Burton, JK 2013, 'Second Life in education: A review of publications from its launch to 2011', British journal of educational technology, vol. 44, no. 3, pp. 357-71, CrossRef

- Warburton, S 2009, 'Second Life in higher education: Assessing the potential for and the barriers to deploying virtual worlds in learning and teaching', British journal of educational technology, vol. 40, no. 3, pp. 414-26, CrossRef

- Zelenskaya, K \& Singh, N 2011, 'Exploring Virtual Recruiting From Employers' Perspective Using "Second Life"', Journal of Human Resources in Hospitality \& Tourism, vol. 10, no. 2, pp. 117-28, CrossRef

- Zikmund, WG \& Babin, BJ 2007, Exploring marketing research, South-Western Pub. 